\title{
Cooking their Way to Attachment and Binding Family Ties in the Kitchen: A Close Reading of Select Food Literature
}

\author{
Anupama. D. Thampi and M. G. Priya \\ Department of English Language and Literature, Amrita School of Arts \\ and Sciences, Amrita Vishwa Vidyapeetham, Kochi, India
}

\begin{abstract}
In the post-modern relentless race for money and other material possessions, family bonds seem to have lost strength and significance. Parenting has assumed difficult dimensions and the related issues are a pressing concern of the day. This paper aims to examine the attachment between parents and children through the paradigm of "cooking". Cooking food using the traditional recipes extends a sense of belonging and connection between the different generations. Family recipes build delicious memories and experiences from the past. Through a close reading and thorough analysis of Amulya Malladi's Serving Crazy with Curry (2004) and Meera Ekkanath Klein's My Mother's kitchen: Novel with Recipes (2014), this paper portrays the value of family cooking. Kitchen forms the backdrop to contour the intricate lines of the special bond of the mother-daughter relationship in these novels. In the light of John Bowlby's Attachment Theory, this paper proposes to explore the idea that family attachments can be accrued through the art of cooking.
\end{abstract}

KEY WORDS: MOTHER-DAUGHTER RELATIONSHIP, ATTACHMENT THEORY, FAMILY ATTACHMENTS, COOKING, KITCHEN.

\section{INTRODUCTION}

The first relationship of attachment that we develop is with our mother and then with our father and the immediate family in the course of time. It is believed that our relationship with our parents influences the development of all our future relationships also. Attachment is defined as "affection, fondness or sympathy for someone or something." it is a feeling of love and need for another person, for example for a mother by her child (Calmsage). Attachment is profound and is an ongoing association built up between a child and its caretaker starting in the initial stages of its life and developing over time. Attachment creates a special bond between parents and children and leads to a mutually happy relationship. It permits youngsters to develop a safe base and helps to investigate, learn, and relate things around them. The psychological process of attachment is significant to get

Biosc Biotech Res Comm P-ISSN: 0974-6455 E-ISSN: 2321-4007

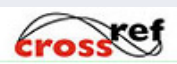

Identifiers and Pagination

Year: 2021 Vol: 14 No (8) Special Issue

Pages: $33-38$

This is an open access article under Creative

Commons License Attribn 4.0 Intl (CC-BY).

DOI: $h$ ttp://dx.doi.org/10.21786/bbrc/14.8.8 rid of unnecessary stress, and it helps an individual to build mental strength and versatility.

This paper treats how family attachments are viewed from the perspective of "Cooking" to reveal the significance of the art of cooking to strengthen family ties. Towards this end, Amulya Malladi's Serving Crazy with Curry and Meera Ekkanath Klein's My Mother's kitchen are analysed in depth. The objective of the study is to exhibit the representation of cooking as a source of attachment among family members with instances from the selected novels. The primary focus of the study is through the lens of John Bowlby's Attachment theory.

Objective and Scope: In the present-day materialistic world, people are busy running behind technological advancements and material gains. There is a lack of attachment and lack of communication within families and hence, a study of this nature that propounds the importance of kitchen and the significance of cooking in a family, investigating the space of kitchen as a setting for expressing familial feelings and communicating for and through cooking, helps to maintain and strengthen the attachment within families. Thus, the scope of the study is to analyse selected novels depicting food and culinary art as a predominant content in order to convey
Article Information

Received: $10^{\text {th }} \mathrm{Apr} 2021$

ccepted after revision: $12^{\text {th }}$ June 2021 
the significance of cooking in creating a common family space charged with positive energy of attachment.

\section{RESULTS AND DISCUSSION}

In the present-day world of Zomato and Swiggy, when we have lost the ways of traditional cooking and have moved over to online ordering of food, families have lost connection and are engaged with personal laptops or cell phones, moving into "personal space" and moving out of the "common family space". Literature is a representation of life in its various aspects. Literature influences and is influenced by these multifarious aspects like social, religious, economic and political spheres. This varied influence leads to a wide range of critical study in the field of literature and multidisciplinary study has become the order of the day. This paper is an amalgamation of Food Studies and Psychology in Literature. John Bowlby introduced the Attachment theory in the field of Psychology.

Bowlby is outstanding as both therapist and psychoanalyst and also exhibits a colossal enthusiasm for child development. He became a physician in the Kids Direction Center at London during the 1930s and has handled numerous extremely resentful children. This experience has led him to understand the strength of the relationship between children and their mother with regard to their social interaction and the emotional pattern of the infants. In general, it shaped his perception about the association between mother and child and this experience led Bowlby to give shape to his Attachment theory in depth.

The core principle of Attachment theory evolves from the ideas taken from Ethology and Developmental Psychology, which were presented to the British Psychology Analytic Society of London in three exemplary articles: "The Nature of the Child's Tie to his Mother" (1958), "Separation Anxiety" (1959) and "Grief Mourning in Infancy and Early Childhood" (1960). After presenting these papers, Bowlby dismissed psychoanalytic clarification for theory and consequently psychoanalysts dismissed his theory. At about a similar time, Bowlby's previous associate, Mary Ainsworth, was concluding board observational investigations on the idea of new born child connections in Uganda in the view of Bowlby's Ethological Psychology. Her outcomes and other investigations become the subsequent base for the evidence of attachment hypothesis in 1969. The primary volume of the Attachment and Loss Trilogy, the second and third volumes - Separation: Anxiety and Anger and Loss: Sadness and Depression, were published separately in the year 1972 and 1980. John Bowlby gave the definition of attachment as "lasting psychological connectedness between human beings" (qtd. in Simply Psychology).

As demonstrated by Bowlby, when children go through pressure or stress, they search for closeness with their guardians. He saw attachment as a result of transformative cycles, while behavioral theory recommended that connection was a scholarly cycle. Bowlby proposed that kids are born to the world with a characteristic drive to outline associations with parental figure. The main theme of Attachment theory is that important guardians who are responsive and attentive to the needs of a baby help the child to establish a feeling that everything is all right in the world. As said by Robert Browning: "God is in his heaven, all's right with the world." The baby knows that the caregiver is trustworthy, and this presumption gives the young one a safe basis for exploring the world.

Examination of Bowlby's Attachment hypothesis shows that when newborn children are put in new situations and are separated from their parents, they respond more to get together with relatives in three different attachment patterns: The first pattern is secure attachment, where the babies displayed misery on separation, but if the parents came, they found warmth and changed quickly. Anxious resistant attachment is the next pattern, where some of the newborn kids encountered a higher amount of discomfort and departed after re-entering with the parents. The third pattern is Avoidant attachment, where the infant displayed no strain of insignificant concern on the guardian's parting or otherwise ignored the guardians after re-entering or successfully managed to evade their guardian. For later days, the specialist referred to this rundown a fourth attachment type, the disorganized disoriented attachment type, which applies to children who do not have an expected example of attachment practice. (Very well mind).

The attachment theory is the most common speculation about the development of young people and over the previous years has gained a lot of regard from clinicians and specialists all over the world. It has also received the attention of clinical experts, teachers, lawyers, government leaders and policy makers and is the focus of literary research, social work packages, and in the advancement of careers. There are a lot of literary works that portray the art of cooking. Writers from the ancient times as well as the contemporary times across diverse cultures have celebrated its might. Many writers like Chitra Banerjee Divakaruni, Nani Power, Jael Mc Henry and Ruth Rechl, to name a few, have shown the significance of cooking as well as the importance of food in human lives. The literary works represent food in a number of ways. Studies on Food Literature are in vogue with the emergence of the latest trend of interdisciplinary research. Such studies include food and culture, food and gender, food and emotions, etc.

In the article "Self-acceptance by serving food in Amulya Malladi's Serving Crazy with Curry," the author attempts to demonstrate how cooking is necessary for an individual to accept one's self by analysing the specific character "Devi" from the novel. Another article "Cookery or Creativity? A Study of Culinary Fiction of Chitra Banerjee Divakaruni, Amulya Malladi and Esther David", tries to analyze three novels by these authors, to showcase the creative zeal in cooking. There is not much critical research done in the other selected primary work, My Mother's Kitchen, only book reviews are available 
as secondary resources. So, this paper is an attempt in the field of Psycho-social study of literature, exploring the importance of cooking in a familial structure by prioritizing the development of attachment through the analysis of various characters of the selected novels. Family bond between its members is vital, as it helps people to manage any situation and it also creates a pleasant atmosphere inside the home.

Lack of attachment results in various issues which can even lead to grave psychological problems. The most prominent resultant issue is that of anger management. Therefore, family connection and affection through attachment is of prime importance. In general, children with no parental attachment exhibit powerless social and socio-emotional impact, such as criminal tendencies, weak ability to solve problems, academic weakness, rage outburst, etc. These negative impacts affect individuals all through their developmental years and often result in juvenile delinquency. A recent news article titled "Pune :13-year-old boy calls 2 minors to play, sexually abuses them; booked", (Times now news) is a grave instance of an individual's transformation to a criminal due to lack of attachment in family. The above article discusses a case that happened in Pune city, where a boy sexually harasses two boys who were younger than him. This shows how a person transforms to a criminal due to lack of attachment within the family.

There are some potential approaches to bring back the family association like watching movie, eating dinner, baking, cooking, playing games, reading, walking and engaging in craft work, together. This study concerns about the cooking activities that engage a family in getting closer together and how it helps develop a wellknit, healthy and happy family. Food unites individuals and cooking at home is considered to be an excellent method to join family members over the kitchen cabinet and the dining table. Everybody adores home prepared food because it is healthier than junk food. Receiving grateful inputs and appreciation for one's cooking lifts a person's confidence. Cooking aids in bringing the family together, although done with an intention to ease the drudgery of the task and also incidentally brings them closer to each other. Helping each other during cooking, relatives can formulate deep rooted recollections. The cycle of home cooking is a method of planning food with the formula of affection.

The time devoted in the kitchen encourages the family members to get an opportunity to talk to one another, particularly with regard to the Indian method of cooking, the craft of cooking is passed from one generation to the next, particularly from mother to the girl child. And likewise cooking assists with tackling issues among relatives by conveying food plans or recipes and building solidarity on the kitchen table. The creativity in the process of cooking can assist in creating happiness and also in expressing their emotions. Amulya Malladi is an Indian author and a talented storyteller who is famous for writing about the theme of the immigrant community. She was raised in the state of Madhya Pradesh, completed her graduation in Electrical Engineering from Hyderabad and her Master's in Journalism from United States, and is presently staying with husband and two sons in Denmark. Her works include, A Breath of Fresh Air (2002), The Mango season (2003), Serving Crazy with Curry (2004), Song of the Cuckoo Bird (2005), The Sound of Language (2007) and A House for Happy Mothers (2016). A Significant number of her books have been translated to various languages like German, Spanish, Danish, Romanian and Tamil. Most of her books are concerned about joy and sadness experienced in human life and also give importance to both career and personal life. In an interview, she says:

I want to tell the story of a career woman who doesn't have to give up her career because she realizes that her family is more important - no, I want to tell the story of a woman who has her career, the family and whatever else she wants. I want to tell the story of a woman who has a nervous breakdown and takes the time to get better; not someone who drags herself through life becoming smaller and smaller until she disappears into her darkness of depression and no one even notices that she's not there anymore. (Jaggery).

In Serving Crazy with Curry, Malladi shows how the relationship between the California immigrant protagonist Devi and her mother is maintained through the act of cooking. At the beginning of the story, the motherdaughter relation is strained and slightly negative, but towards the end of the book, their bond becomes strong through their act of cooking. Devi is considered to be a failure in her personal and professional life. She is depressed to the extent of deciding to kill herself. Before the ultimate moment of committing suicide, she made a spreadsheet and listed out all the reasons for dying and also those for not dying. There were many reasons to die, such as having an abortion, falling in love with a married man, being completely in debt and unable to pay rent, etc.

The prime reason for her to not commit suicide was that she had a great family. Before committing suicide, she thought of calling her father Avi vetura, who is a wealthy man who owns a Technology company. She was not able, however, to talk to her mother. Since her mother spends her entire life in the kitchen, Devi does not like her mother, and does not want to be compared with a mother who has no achievements. And neither was she happy with her sister, Shobha, who is the Vice President of a software firm. And her grandmother Vasu was also a Doctor in the Indian Army. Like her other family members, Devi was not successful and that was a major cause of her depression.

Her mother asked her for a spare key to her rented house, and kept a box of ladoo for Devi for the first time. She loves her mother, but she would not communicate her affection. She made a vertical wound on her left hand after seven months of stress, and her mother saves her life since she has the spare key with her. She used her phone to inform 911: “Avi come now. Now. Our baby's 
dying, now,"she cried out..." (Malladi,18). After the suicide attempt, Devi stopped talking otherwise and she preferred the interaction over cooking and shared her emotions. Mother Saroj tried to teach her daughters about cooking during the childhood of Devi and Shobha.

Shobha was of the opinion that cooking was not for successful women; Devi would start asking questions about cooking but had no involvement in cooking a meal. In the novel, the protagonist asks some very pertinent questions to her mother: "why can't we add parsley in the dal? Devi would ask. Because Indians don't use parsley, only coriander, Saroj would say. Why can't we make a duck curry or rabbit curry instead of a chicken curry? Do we always have to have the same chicken curry? Devi would want to know. Because Indians don't eat duck or rabbit or deer or any of those repulsive meats, Saroj would respond". (Malladi 16). Devi had been a troubled and frustrated girl during her childhood - she stole money from her mother, even hit her classmate Lilly and also kissed one of the white guys named Dylan. At this Saroj burst out to her, making her sad and she left the house as she had no attachment to her family.

After her discharge from Sequoia hospital emergency room in Redwood city, Devi came to her parents' home. Saroj put the white bedsheet where the lavender painting was engraved. Devi was very satisfied to see white sheet, she also saw the bookshelf of her mother, where R K Narayan's, Anita Desai's and some books on cooking that were gifted to her mother, were kept. She saw the recipe of "GIRIJA'S GOAT SABAZI" (Malladi 62) on that cooking book that was the first perception about cooking for Devi, while she stopped talking, Avi sent her letter to show his sweet daughter the love and support: "I will hold your hand through this. I will grab you hand and hang on until this is over. I will tie you up, imprison you, until I make you realize that your life is worth living that your life is brilliant, that you are an amazing girl, You are the one who makes the sun shine brighter for me. I love you; Devi live for me! Daddy” (Malladi 66).

The readers clearly view the change in Devi, who had never been interested in cooking, being transformed in the second half of the novel to a person who wants to taste new spicy recipes. Her first attempt to cook is "The Anti Saroj chutney" (Malladi 74), as she could never connect herself to her mother's cooking. Then she made Cajun Prawn Biriyani on the eighth day of her return from the hospital, to celebrate the moments of having her license back, and ironically, Avi, who hates prawns, would be the only one who completed his plate. Then Devi drops her idea of suicide and decided to start her life over again.Devi likes a lot to cook, and begins to engage most of her time in the kitchen, cooking new dishes, chopping. Baking, etc.

When her grandmother wanted to visit her friend in India, owing to anger, Devi made a spicy food and named it "Angry at vasu Grilled chicken in blueberry Curried sauce" (Malladi 118). Thus, through cooking, Devi started to express her mood - if she was frustrated, she prepared spicy food, if she was happy, she made desserts, and on the whole, she started to enjoy cooking. In processing Rasam powder, Saroj helped her a lot, Later Devi prepared a special pastry and it became an instant favorite of the family and it brought Saroj and Devi closer to each other. Together, they began to cook and started to communicate with each other, Saroj asks: “God knows I didn’t teach you, so where did u learn? Devi smiled and pointed to Saroj. From me? Saroj asked surprised "Really" Devi nodded with a smile and Saroj smiled back, her pride shining in her eyes." (Malladi 129).

"Then she made Sooji Ladoo to convey her affection for Girish, and the dish was called "GIRISH'S FAVOURITE WITH A TWIST" (Malladi 144), but later Girish moved to the university of 0xford. At that time, her family heard about the hidden abortion and Devi's relationship with the sister's husband. Then, one day she made a "LAMB CLITORIS" (Malladi158) - a wild dish with traditional spices and pomegranate. Saroj did not get angry at her even after learning about Devi's abortion, instead, she hugs her and did not force her to say anything else about the incident. This incident and her mother's response to it triggers the spark of love in her for her mother. Then slowly she began to enjoy the Indian recipes of her mother, especially “DOSA WITH SAMBAR” (Malladi 205), and on that very day Devi takes a major decision in her life and chooses to go to a culinary school and this is how the mother-daughter duo rebuild their kitchen with love and affection: "My Memories of Sunday mornings of eating Hot Dosa with sambar and pickle are vivid. I am glad that I am living here again so that I learn to appreciate the one thing that I never did learn to do before; Mama's impeccable south Indian cooking." (Malladi 206).

With love and deep attachment, the mother and daughter bonded in the kitchen, and Devi admitted that her mother guided her a lot, because Saroj was the one who taught her cooking and cleared all her doubts about cooking, and in the process, inspired her entire life. Even when Devi stopped talking, the silence in the kitchen made them interconnected. Devi enjoyed her life as it got better with the process of cooking. Saroj does not like anyone entering the kitchen initially, but she also changed with Devi later in order to make her happy.

At the beginning of the novel, the protagonist did not appreciate traditional Indian cooking of her mother, but towards the end of the novel, their attachment became lovely. Through the backdrop of cooking, Amulya Malladi demonstrates a real-life mother-daughter relationship. Cooking food allows one's mind to remain busy and in the case of Devi, it helps her conquer the fear of life and kitchen becomes the stage where Devi gets an outlet to demonstrate her new culinary skills. The novel also reveals that cooking food is the "love and happiness" formula. Each event that occurred to the protagonist has a specific emotional recipe and that is how the beautiful relationship of the mother and daughter connection was born in the kitchen with the support of food recipes. 
In Meera Ekkananth Klein's My Mother's kitchen, also kitchen forms the ground for the mother-daughter bonding and sets the foundation for the deep attachment between the two. Meera was born in India but now stays with her husband and the two grown-up children in Davis. She was a newspaper reporter and tries to give nostalgic memories of her days in south India through her work, which has autobiographical elements as Meera herself learnt the recipes of Indian cooking from her own mother. This novel aims to explore how the kitchen becomes an interaction paradigm that leads to an enduring relationship between a mother and her daughter. This novel contains narratives with recipes, each tale has recipes linked to the experiences of the characters.

The protagonist Meenakshi, shortly named as Meena, is sharing her childhood memories within the story. Her father Unnikrishnan, who owns cashew plantation at Chandur, is seen coming home every second Saturday, and hence Meena is more attached to her mother Sudha. Everyone calls her as "Little mother". After Sudha's and Rukamani's parents died in an accident, they were staying at uncle Ramu's house, and there also cooking becomes a mode of communication because Sita made an attachment with them in the kitchen; she asked Rukmini to stir suji and asked Sudha to peel the cardamom pods for making pudding and that's how they become attached in that little dark and smoky kitchen.

Meena tells about the kitchen of her mother at the beginning of the novel as a magical place, since recipes were added and it was turned into tasty dishes such as the lemon rice of her mother. The kitchen was a normal place, but it was so interesting. Their residence had two rooms - the first room was full of furniture and the second part of the room was where the process of cooking actually took place, Meena once says: "The morning is a busy time in the kitchen with cow hands bringing in pales of fresh milk" (Ekkanath 12). All the villagers like her a lot because she has a helping mentality, when kasi had a problem she used to go to Meena's mother: "I felt like I was home when I came in to this kitchen you and this house are a refuge for people like me" (Ekkanath 40) Every second Saturday was special for Meena and her mother because her father would come, so her mother would be busy cleaning the house and making food for him. She made AVIYAL STEW (Ekkanath33), rice pudding, etc. to commemorate the mark of the new year and the harvest festival of Vishu. Meena helped her mother to peel off the cardomon pods. Meena gave a description of the temple and also prays for getting a baby sister: "I leaned head against my mother's shoulder and smack my lips, savouring the nutty taste of the chickpeas snack in my mouth" (Ekkanath47).

Devi cooked a lot of food to fill the stomach of her mother and Meena and her mother enjoyed eating them, that day Devi made "ISHTU" (Ekkanath59) for mother, and then she delivered two babies and Meena was so happy and excited, after a naming ceremony and they were called Thangam and Appu. At that time, the kitchen became dusty and full of ginger fragrance, and Devi was busy cutting vegetables for Aviyal and preparing tomato chutney as well. Meena and her mother went to see the flower show where they saw Jawaharlal Nehru and that moment become special for Meena. They took packed food with them, which included tomato rice and curd rice. Eating together and cooking together makes people happy. One day she went to the house of her friend, Kumari, and played with her and ate the sweet dish called "Sandesh" (Ekkanath83). She expressed her love towards her mother and also about kitchen thus: "Just like her soothing presence, my mother's kitchen is a place of comfort and solace" (Ekkanath105).

One night, a thief entered their home and ate the leftover food, but he was not punished by Meena's mother, she made Jaibal her driver. Meena made a new friend named Priya from the Dhobha village, and settlers regard them as robbers, but her mother welcomed her to eat and made her coconut rice, and this shows her mother's magnanimity. On the day before Deepavali, the festival of lights, the kitchen was full of delicious memories: "Tomorrow my mother and I will go deliver these sweets to neighbors and friends" (Ekanath147) After her father died, her mother was highly depressed, and Meena feels that "Without my mother, the very heart of the kitchen is missing" (Ekkanath227). When she saw all the spices in the kitchen, she experienced great pain because it made her think about her father, and later Meena asked her mother to teach her cooking. Towards the end of the novel, we find her uncle pressurizing Meena to marry a man, and they made a lentil cake and called the dish "Seeing CEREMONY LENTIL CAKES" (Ekkanath 251).

The author typically gives importance to Indian cooking in this novel, most part of the novel takes place in the kitchen, and the plot has been set up traditionally. It also demonstrates the pure relationship between Meena and Sudha, and expresses how they preserved their attachment through cooking. And this is how Meera Ekkanath Klein pens down the concept of attachment in the backdrop of the kitchen.

\section{CONCLUSION}

This paper explored two novels which are concerned about the mother-daughter relationship firmly based on the perspective of cooking and are laid in the backdrop of the kitchen. The central character Devi was initially devoid of attachment to her mother; but by the end of the novel, she develops a strong bond with her mother and the readers observe this transformation was made possible only because of cooking. Cooking plays a quintessential role in expressing emotions as well. The character Meena shows the significance of cooking from her childhood memories and also expresses her inner emotions through cooking - rage is expressed through spicy food and love is expressed through cooking sweet dishes, etc. Cooking plays an important role in reunions as well and kitchen forms the ground for the family 
members to interact with each other. Thus, kitchen has a deep role to play in everybody's life in the novels considered.

In this consumerist money-oriented world, lack of attachment is a great concern. People are not attached to one another. Lack of communication is another pertinent problem. People have turned out to be materialistic and technologically advanced and have come to a state that the major source of communication today is through the virtual media. Unfortunately, virtual media can only develop a virtual relationship. So, developing attachment is of utmost importance and therefore this topic is of great relevance in the contemporary scenario. This study proves how kitchen can form the ground for togetherness and cooking can help to develop a bond between people.

\section{REFERENCES}

Cherry, Kandra. "What Is Attachment Theory? The Importance of Early Emotional Bonds".

Verywellmind.www.verywellmind.com/what-isattachment-theory-2795337, 2019.Accessed 1Mar2021.

Dermendzhiyska,Elitsa. "How you attach to people may explain a lot about your inner life ".The Guardian.www.theguardian.com/science/2020/jan/10/ psychotherapy-childhood-mental-health,2020. Accessed 20 Jan 2021.

Ekkanath Klein, Meera. My Mother's Kitchen: A Novel with Recipes. Homebound Publication,USA, 2017.

Malladi,Amulya. Serving Crazy with Curry. And Then She said Press, 2018.

Mcleod, Saul. “AttachmentTheory”.SimplyPsychology. www.simplypsychology.org/attachment,20 17. Accessed 25 Jan 2021.

Mahadev, Anu. "An Interview with Amulya Malladi”. Jaggery. www.jaggerylit.

com/an-interview-with-amulya-malladi/,2018. Accessed 28 Jan 2021.

"Pune: 13-year-old boy calls 2 minors to play, sexually abuses them; booked".TimesNowNews.com.www. timesnownews.com/pune/article/ pune-13-year-oldboy-calls-2-minors-to-playsexually-abuses-thembooked/678544, 2020.Accessed 13 Feb 2021..

Sharma, Swaranakshi. "All you need to know about Ambivalent Attachment”. Calmsage.www.calmsage. com/ambivalent-attachment/,2021. Accessed Mar 25, 2021. 